\title{
ANALISIS PERAN PEREMPUAN DALAM MEMANFAATKAN POTENSI LOKAL SEBAGAI ALTERNATIF USAHA DI KAMPUNG TANJUNG TALOK DESA TELUK SASAH KABUPATEN BINTAN
}

\author{
Indah Andesta ${ }^{1^{*}}$ \\ ${ }^{1}$ Prodi Diploma III Perjalanan Wisata Politeknik Bintan Cakrawala \\ ${ }^{*}$ Corresponding author: andesta56@gmail.com
}

To cite this article:

Andesta, I. (2021). Analisis Peran Perempuan dalam Memanfaatkan Potensi Lokal Sebagai Alternatif Usaha di Kampung Tanjung Talok Desa Teluk Sasah Kabupaten Bintan. Jurnal IImiah Membangun Desa dan Pertanian, 6(6), 202 - 212. doi:http://dx.doi.org/10.37149/jimdp.v6i6.21225

Received: October 20, 2021; Accepted: December 10, 2021; Published: December 15, 2021

\begin{abstract}
Research involving women's Tanjung Talok Village as the object of study aims to analyze the role of women in utilizing the local potential and can be used as business products in Tanjung Talok Village. In Tanjung Talok village, there are five local communities (groups), and each group has one effect of being developed. This study did in Tanjung Talok village from March until July 2021. Furthermore, the research uses qualitative and quantitative methods. Researchers conducted indepth interviews, observations, and literature reviews. The data obtained were analyzed by a qualitative descriptive approach. The variable in this research is women in Tanjung Talok village who have still productive to develop a small business product. The results showed that the role of Tanjung Talok in utilizing local potential was not maximized. From a total of 104 family data, it was known that women who had businesses based on local potential were 15 women with products such as fish crackers, gamat oil, chips, peanut brittle, chili paste, and other small businesses. The role of Tanjung Talok women is maximized by having a business group with Tanjung Talok's women to develop small Business or household products. Most women in Tanjung Talok have the skill to process those products. Marketing and packaging are challenging to create those products due to women in Tanjung Talok don't have much talent or experience on their part. The following research has to focus on analyzing the effectiveness of the management model that will apply in Tanjung Talok village.
\end{abstract}

Keywords: women's role; small business; local potential

\section{PENDAHULUAN}

Nelayan merupakan salah satu kelompok yang menggantungkan perekonomiannya pada sumber daya kelautan. Kegiatan perekonomian di kawasan pesisir tidak dapat dilepaskan dari peran perempuan. Perempuan memiliki peran ganda dalam kegiatan sehari-hari, selain menjalankan peran domestik perempuan pesisir juga dituntut untuk melakukan kegiatan yang dapat mendukung perekonomian keluarga. Peran perempuan pesisir dituntut aktif untuk memasarkan hasil tangkapan dan untuk memerankan sebagai ibu rumah tangga (Nwabeze et al., 2012). Peran ganda perempuan tersebut sangat identik dalam penurunan kemiskinan (The Role of Women in Fisheries, n.d.). Dengan peran ganda yang dimiliki perempuan pesisir tersebut, mereka harus mencurahkan waktu lebih banyak daripada kepala keluarga, kegiatan telah dimulai sejak bangun tidur sampai saat mereka istirahat dimalam hari (Nurlaili \& Muhartono, 2017). Mengingat pentingnya peran perempuan pesisir dalam membantu perekonomian rumah tangga sehingga perlu melibatkan perempuan dalam program-program untuk peningkatan perekonomian (Tahawila, n.d.). Program-program dalam peningkatan perekonomian di kawasan pesisir baik dari pemerintah, lembaga, dan pihak swasta. Salah satu program yang dibentuk oleh PT. Bintan Inti Industrial Estate (BIIE) yaitu membentuk kelompok bersama yang melibatkan perempuan sebagai penggerak pertama dengan memanfaatkan potensi yang dimiliki kawasan tersebut. Program tersebut dikenal dengan istilah KUBE di Kampung Tanjung Talok Kabupaten Bintan. Tanjung Talok merupakan sebuah kampung pesisir yang terletak di Kabupaten Bintan Kepulauan Riau. Mayoritas masyarakat di Kampung Tanjung Talok berprofesi 
sebagai nelayan. Tidak hanya kepala keluarga yang dituntut untuk memenuhi atau membantu perekonomian keluarga tetapi diperlukannya peran wanita dalam meningkatkan perekonomian keluarga. Kondisi tersebut disebabkan hasil tangkapan nelayan yang tidak stabil dan disebabkannya dengan hasil tangkapan nelayan yang semakin menurun. Menurunnya tangkapan nelayan disebabkan oleh berbagai hal mulai dari perubahan cuaca dan jalur transportasi laut. Hal tersebut menuntut perempuan untuk memiliki peran ganda baik bekerja pada area domestik dan sebagai salah satu penggerak perekonomian keluarga.

Selanjutnya, tantangan tersendiri yang dimiliki oleh perempuan pesisir dalam meningkatkan perekonomian keluarga yaitu terdapatnya keterbatasan pada pendidikan yang berdampak kepada lemahnya keterampilan yang dimiliki oleh perempuan pesisir (Anggraini, 2018). Tantangan tersebut terlihat pada tingkat pendidikan perempuan di Kampung Tanjung Talok. Sehingga kegiatan dalam peningkatan perekonomian rumah tangga hanya sebatas lokal yaitu penjualan produk rumahan yang dihasilkan seperti kerupuk ikan sebetas hanya diketahui oleh tetangga dalam Kampung Tanjung Talok sendiri. Usaha kecil yang dijalani oleh perempuan Kampung Tanjung Talok tidak hanya sebatas membuat kerupuk ikan. Kegiatan lainnya seperti ikan asin, rempeyek, keripik dan sambal lumat yang merupakan sambal khas masyarakat melayu. Sehingga penting untuk dapat mengetahui peran dan rencana ke depan dari perempuan Kampung Teluk Sasah dalam memanfaatkan komoditas potensial yang ada di Kampung Tanjung Talok.

Komoditas potensial yang dimiliki suatu daerah seperti rumput laut di NTB belum maksimal dalam meningkatkan pembangunan ekonomi lokal, hal tersebut dapat dipengaruhi oleh fokus dari pemerintah dalam mengoptimalkan komoditas potensial yang dimiliki suatu wilayah. Hal tersebut terjadi di NTB, dimana fokus pemerintah yaitu pada bisnis, tidak pada level mikro atau masyarakat. Sehingga, dalam praktik selanjutnya, pemerintah NTB telah merancang blue ekonomi yang mendukung pembangunan berkelanjutan pada rumput laut. Tidak hanya itu, faktor pengepul menjadi salah satu penghambat pembangunan ekonomi lokal menuju keberlanjutan (Hidayat \& Safitri, 2019).

Komoditas potensial disuatu daerah tidak hanya sebatas produk, tetapi media pembelajaran literasi yang terdiri dari membaca, menulis, berhitung, berbicara dan menyimak. Dalam mendukung ekonomi rumah tangga, perempuan pesisir melakukan multi peran sebagai ibu rumah tangga dan melakukan pekerjaan yang dapat meningkatkan perekonomian keluarga seperti tukang cuci, pemanggangan ikan, assisten rumah tangga, dan lain-lain. Dimana perempuan di daerah pesisir telah memiliki keterampilan seperti olahan lauk berbahan dasar ikan, pengolahan ikan asin, pengasapan ikan, dan lainnya. Sehingga model literasi berbasis entrepreneurship sangat membantu dalam mengembangkan potensi yang dimiliki perempuan nelayan yang bertujuan untuk pemenuhan minat dan untuk mengaplikasikan kemampuan dan keterampilan baru yang diperoleh untuk meningkatkan taraf hidup (Hidayatullah \& Suminar, 2021).

Penelitian yang dilakukan oleh (Hendriyana et al., 2020) menjelaskan mengenai industri kreatif yang ramah lingkungan sebagai produk kriya pandan yang dapat dimanfaatkan sebagai daya tarik wisata di Pangandaran. Model desain yang diterapkan yaitu mendukung pariwisata kawasan dengan mengingat multi fungsi dari potensi daun pandan. Selanjutanya, startup bisnis dengan mengoptimalkan keberadaan pemuda dan peremuan di kawasan Pangandaran. Dalam praktek nya diperlukan keterampilan dan desain yang ramah lingkungan untuk mendukung kegiatan ekowisata di Pangandaran. (Nawawi et al., 2020) melakukan pengelompokan komoditas lokal untuk membangun kewirausahaan sosial dibagi menjadi hutan, sungai, goa, danau, kebudayaan dan batu bara di Kabupaten Berau. Pengelompokan komoditas lokal dilakukan untuk mengurangi defortasi di kawasan Kabupaten Berau.

Alat tangkap menjadi suatu hal penting dalam penangkapan ikan untuk keberlanjutan komoditas potensial di pesisir. Alat tangkap juga berhubungan dengan penurunan atau kenaikan keuangan, dimana produksi dan kebutuhan nelayan semakin meningkat. Teknologi yang diterapkan hendaknya menerapkan praktek ramah lingkungan untuk menjaga keberlangsungan sumber daya perikanan (Hariyanto et al., 2008).

Menganalisis komoditas potensial, penelitian yang dilakukan oleh (Kamil \& Hapsari, n.d.) menerapkan model klaster yang menghasilkan 16 jenis usaha dan 14 usaha produk bahan makanan dan 2 usaha produk lainnya. Model klaster ini dapat diterapkan dengan mempertimbangkan sarana yang lengkap dengan hasil laut yang melimpah.

Peran perempuan di wilayah pesisir belum pada proses transformasi yang lebih aplikatif untuk kegiatan peningkatan perekonomian rumah tangga. Dimana perempuan pesisir belum dapat mengeksplor lebih dalam lagi potensi yang mereka miliki untuk lebih mandiri dan berkarya hal tersebut dipengaruhi oleh keterbatasan pendidikan dan keterampilan (Astanty, n.d.). Penelitian yang dilakukan oleh (Amsal \& Junawati, n.d.) menjelaskan bahwa peran ganda yang dilakukan oleh perempuan pesisir dapat berupa domestik dan publik. Dimana peran publik dapat dibagi menjadi dua 
yaitu peran sebagai pedagang menjual hasil tangkapan nelayan dengan membuka warung di rumah dan peran sebagai pengelolaan hasil tangkap ikan. Pengolahan hasil perikanan merupakan suatu kegiatan ekonomi produktif perempuan di kawasan pesisir. Dalam pengolahan ikan, tidak diperlukan keahlian khusus, sehingga hal tersebut tidak menghambat perempuan pesisir dalam melakukan pengolahan hasil perikanan (Anggraini, 2018). Peran ganda perempuan pesisir sangat diperlukan dalam meningkatkan perekonomian keluarga. Menurut (Pembentukan Model Pemberdayaan Perempuan Nelayan Di Daerah Tertinggal, n.d.) perempuan pesisir memiliki watak yang keras dan manja dengan melimpahnya sumber daya alam yang dimiliki. Tetapi pada kenyataannya, perempuan pesisir memiliki peran ganda, disamping memenuhi kebutuhan domestic juga berperan untuk meningkatkan perekonomian.

Pada penelitian yang di lakukan oleh Handoko membuat model pemberdayaan perempuan pesisir atau kampung nelayan yang terdiri dari beberapa program seperti bantuan peralatan modal usaha, penyadaran masyarakat, pelatihan keterampilan pemeliharaan bandeng, kepiting, dan udang, pelatihan ketrampilan pengolahan hasil budidaya, dan Kerjasama kemitraan. Program tersebut akan didukung dengan pembentukan koperasi nelayan perempuan dan usaha kemitraan. Dari segi pariwisata, menurut (Andani, 2017) dalam penguatan ekonomi, perempuan pesisir dapat memiliki peran dalam mengembangkan sector pariwisata yaitu untuk mempromosikan tempat wisata, produk dan kegiatan wisata. Terlihat bahwa perempuan pesisir memiliki motivasi yang tinggi dalam mengaplikasikan hasil-hasil pelatihan di bidang pariwisata. Peran perempuan dalam peningkatan perekonomian keluarga dapat didukung dengan memberikan pelatihan-pelatihan keterampilan, memanfaatkan lokasi wisata pantai Ujung Pandaran yang strategis untuk memperluas jaringan pemasaran, melakukan studi banding ke daerah yang memiliki kerajinan limbah hasil perikanan dan memanfaatkan ajang pameran untuk bertemu dengan pengarajin lainnya untuk memperluas usaha dan memanfaatkan bahan baku kelautan (Donna NP Butarbutar et al., 2020). Model pembinaan usaha juga dilakukan pada penelitian (Handajani et al., 2016) yaitu pengolahan abon yang terdiri dari manajemen usaha, promosi, membangun jaringan usaha, mencari pelanggan dan manajemen pemasaran. Hal tersebut dengan mamanfaatkan peran perempuan di area pesisir. Perempuan pesisir memiliki peran yang strategis, hal tersbeut terlihat di wilayah pesisir Teluk Jakarta. Dimana perempuan pesisir memiliki peran pada usaha perikanan tangkap, budidaya kerrang dan pengolahan hasil perikanan. Peran tersebut baik dari segi memperbaiki jarring untuk melaut, memilah hasil tangkapan ikan, mengupas kerrang, memasarkan hasil tangkapan (Nurlaili \& Muhartono, 2017). Pemberdayaan perempuan pesisir telah umum dimana perempuan pesisir melakukan pekerjaan selain menjadi ibu rumah tangga juga di sector industri seperti pengeringan ikan dan ikan belahan (gesek).

Penelitian yang dilakukan di Tanjung Talok merupakan penelitian dasar atau awal dalam mengidentifikasi peran perempuan-perempuan di Tanjung Talok untuk meningkatkan produktifitas melalui pengembangan produk-produk rumahan. Penelitian dibagi menjadi beberapa tujuan yang terdiri dari Identifikasi potensi desa Kampung Tanjung Talok agar dapat mengetahui potensi-potensi apa saja yang dimiliki oleh Kampung Tanjung Talok; Identifikasi peran perempuan Kampung Tanjung Talok baik dari segi nelayan dan perempuan productif di Kampung Tanjung Talok; Tantangan yang dihadapi perempuan Kampung Tanjung Talok dalam pengembangan produk yang memanfaatkan potensi lokal.

\section{MATERI DAN METODE}

Kampung Tanjung Talok, Desa Teluk Sasah, Kabupaten Bintan merupakan lokasi penelitian dengan mengangkat tema mengenai peran perempuan pesisir dalam memanfaatkan komoditas potensial di Kampung Tanjung Talok. Penelitian ini dibiayai oleh PT Bintan Inti Industrial Estate (BIIE) pada tahun 2021. Penulis melakukan penelitian pada bulan Maret - Juli 2021 di Kampung Tanjung Talok dengan variable yaitu masyarakat Kampung Tanjung Talok yang terdiri dari perempuan produktif, perangkat desa, serta nelayan di Kampung Tanjung Talok. Penelitian dimulai dengan melakukan kajian Pustaka, studi lapangan, observasi, wawancara sampai pada tahap mendapatkan informasi-informasi yang diperlukan dalam keberlangsungan penelitian.

Wawancara mendalam kepada perempuan pesisir dan perangkat desa serta observasi di Kampung Tanjung Talok. Penelitian ini tidak terlepas dengan melakukan kajian studi pustaka. Analisis data yang digunakan adalah deskriptif kualitatif, yaitu dalam menganalisis hasil wawancara yang mendalam dan observasi yang dilakukan oleh peneliti. Sample penelitian ini adalah perempuan pesisir yang merupakan istri nelayan dan terlibat dalam kelompok usaha bersama (KUBE) Kampung Tanjung Talok. 
Wawancara telah selesai dilakukan dengan masyarakat kampung Tanjung Talok yang terdiri dari perempuan-perempuan dan RT Tanjung Talok. Wawancara langsung dilakukan di rumah warga dengan melakukan wawancara yang mendalam kepada setiap perempuan yang terlibat dalam perkumpulan kelompok bersama di Kampung Tanjung Talok. Waktu wawancara mengikuti jadwal dari perempuan kampung Tanjung Talok dimana saat waktu senggang dari rutinitas sehari-hari. Hasil setiap wawancara yang dilakukan oleh peneliti dilakukan transkrip untuk dianalisis pada penelitian ini. Peneliti dapat langsung melakukan pengamatan terhadap kegiatan sehari-hari yang dilakukan oleh masyarakat baik dalam kegiatan domestik sebagai kegiatan sehari-hari dan dalam menjalankan usaha kecil. Dalam melengkapi informasi dan pemahaman penulis melakukan wawancara kepada ketua RT Kampung Tanjung Talok dengan tujuan mendapatkan informasi secara keseluruhan mengenai kepala keluarga yang berprofesi sebagai nelayan. Dengan bantuan ketua RT, membagikan kuesioner penelitian untuk data demografi dari perempuan di Kampung Tanjung Talok, informasi yang terdiri dari umur, pendidikan, status, jumlah anak, dan pekerjaan.

\section{HASIL DAN PEMBAHASAN}

\section{Demografi Kampung Tanjung Talok}

Kampung Tanjung Talok merupakan salah satu kampung di Desa Teluk Sasah, Kecamatan Seri Kuala Lobam, Kabupaten Bintan, Provinsi Kepulauan Riau. Masyarakat Kampung Tanjung Talok terdiri dari 128 kepala keluarga. Pada gambar 1, secara umum mata pencaharian masyarakat di Kampung Tanjung Talok sebagai nelayan yaitu sebesar 50 persen dibandingkan mata pencaharian lainnya di Kampung Tanjung Talok.
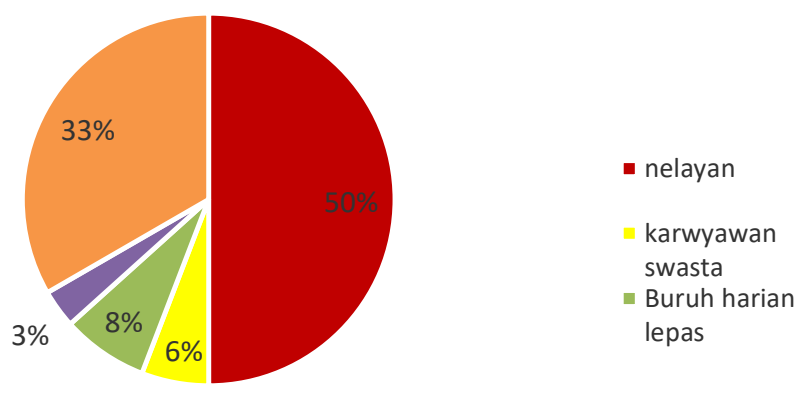

\section{Gambar 1. Mata pencaharian masyarakat di Kampung Tanjung Talok}

Berdasarkan data di atas, dapat disimpulkan 50 persen masyarakat di Tanjung Talok menggantungkan perekonomian mereka pada hasil sumber daya kelautan baik itu berupa ikan, kepiting, udang, sotong dan cumi. Diketahui bahwa, hasil dari melaut merupakan pemasukan yang tidak tetap. Hal tersebut diungkapkan pada hasil penelitian (Adriyani et al., n.d.) bahwa hasil nelayan tidak dapat memenuhi kebutuhan keluarga disebabkan oleh hasil yang tidak menentu sehingga diperlukannya peran dari perempuan atau ibu rumah tangga dalam mengolah hasil laut menjadi produk yang memiliki nilai ekonomi.

Pendapatan dari nelayan tidak menentu, hal tersebut tergantung pada cuaca saat melaut. Interview yang dilakukan oleh peneliti; Pak Basir sebagai kepala RT Kampung Tanjung Talok mengatakan bahwa rata-rata pendapatan nelayan kecil per hari sekitar Rp.100.000, -, sedangkan pendapatan nelayan besar sekitar Rp.300.000, - per hari. Nelayan besar dikatakan mereka yang telah memiliki kelong yaitu alat tangkap ikan tradisional. Biaya yang dikeluarkan untuk pembuatan kelong tidak sedikit, satu kelong membutuhkan biaya kurang lebih Rp.10.000.000, - biaya paling besar disebabkan oleh kawat untuk membuat kelong dan kelong tersebut memiliki umur pakai 1 tahun. Setelah pemakaian selama 1 tahun, kelong tersebut perlu perbaikan, biasanya biaya yang dikeluarkan oleh nelayan dalam perbaikan kelong sekitar Rp.3.000.000, -. Menurut Pak Basir, keuntungan yang paling tinggi saat melaut diwaktu hari raya imlek. Dalam 1 kelong ikan, keuntungan yang diperoleh pak Basir sebesar Rp.3.000.000, -. Total kelong yang dimiliki masyarakat Kampung Tanjung Talok sebanyak 33 kelong. Pendapatan utama di Tanjung Talok adalah dari hasil melaut, masalah yang sangat penting dihadapi oleh masyarakat Tanjung Talok adalah pekerjaan dan sumber daya pendapatan utama hanya dari hasil laut. 
Tabel 1. Karateristik demograpi dari perempuan di Kampung Tanjung Talok

\begin{tabular}{lcr}
\hline Karateristik & & Persentase \\
\hline Umur & $20-30$ & 3.9 \\
& $31-40$ & 35.02 \\
& $41-50$ & 31.07 \\
& $51-60$ & 19.2 \\
\hline Status & $61+$ & 10.7 \\
\hline Jumlah Anak & Belum Menikah & - \\
& Menikah & 77.0 \\
& Janda & 0.8 \\
\hline Level Edukasi Perempuan & 0 & 20.5 \\
& $1-2$ & 18.9 \\
& $3-4$ & 18.0 \\
& $5-6$ & 8.2 \\
& $7-8$ & 2.4 \\
\hline Level Edukasi Laki-Laki & & \\
& Tidak Sekolah & 36.1 \\
& Sekolah Dasar & 16.4 \\
& Sekolah Menengah Pertama & 5.7 \\
& Sekolah Menengah Atas & 26.2 \\
& Diploma 3 & 0.8 \\
\hline & Tidak Sekolah & 37.7 \\
& Sekolah Dasar & 18 \\
& Sekolah Menengah Pertama & 10.7 \\
& Sekolah Menengah Atas & 18 \\
& Diploma 3 & 0.8 \\
\hline
\end{tabular}

Kampung Tanjung Talok, perempuan dengan umur di atas 31 tahun adalah $\mathrm{xx} \% .77 \%$ dari perempuan di Tanjung Talok telah menikah dan rata-rata jumlah anak yang mereka miliki adalah 1-2 anak dengan persentase $18.9 \%$, sedangkan rata-rata anak yang dimiliki oleh keluarga di Kampung Tanjung Talok adalah 2.08. Jika dibandingkan penelitian yang dilakukan oleh (Rad, n.d.) rata-rata anak pada keluarga 2.7, didalam penelitian tersebut (Kaya, 2005) menyebutkan bahwa rata-rata anak yang dimiliki perempuan di Turkey adalah 2.53. Pendapatan dari perempuan Tanjung Talok dapat dipengaruhi oleh pendidikan, dimana $36.1 \%$ perempuan Tanjung Talok tidak bekerja sehingga berdampak kepada pekerjaan perempuan di Tanjung Talok yang tertinggi yaitu ibu rumah tangga, hal tersebut dipengaruhi oleh tingkat pendidikan perempuan Tanjung Talok yaitu $36.1 \%$ tidak sekolah. Hal yang senada dengan penelitian yang dilakukan oleh (The Role Of Women In Fisheries, n.d.) bahwa level perempuan dengan tingkat pendidikan tinggi sangat rendah. Tingkat pendidikan laki-laki di Tanjung Talok tidak begitu berbeda dengan perempuan di Tanjung Talok, 37.7\% laki-laki di Tanjung Talok tidak sekolah dan 18\% menyelesaikan pendidikan pada level sekolah dasar dan sekolah menengah atas.

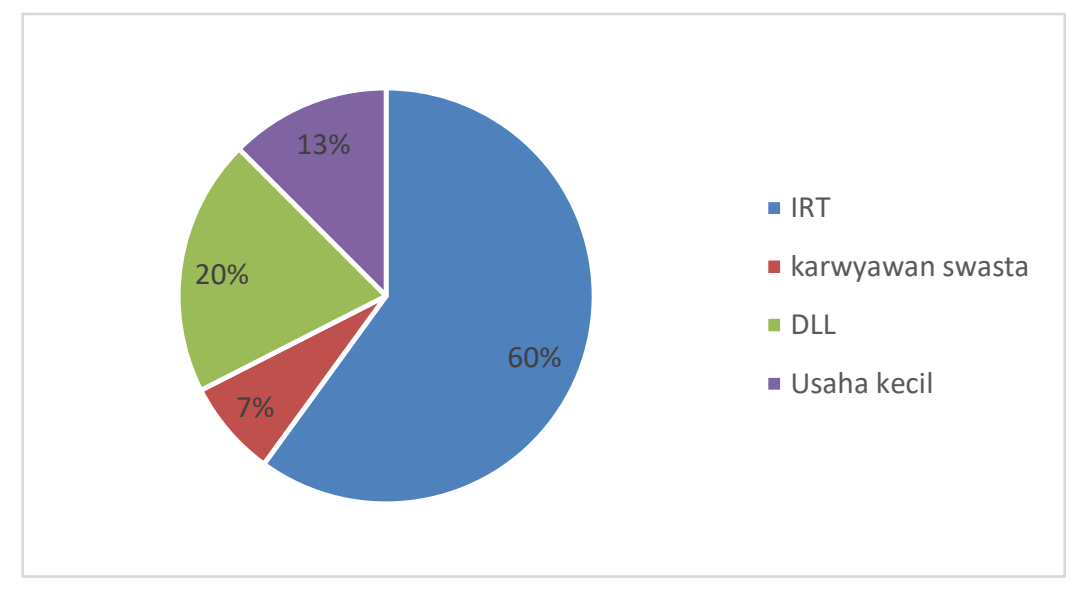

Gambar 2. Mata pencaharian perempuan di Kampung Tanjung Talok 


\section{Potensi Kampung Tanjung Talok}

Kampung Tanjung Talok merupakan kampung yang paling ujung di Desa Sebong Pereh, mayoritas masyarakat memiliki mata pencaharian sebagai nelayan. Dalam memaksimalkan peran perempuan Kampung Tanjung Talok dapat diselaraskan dengan potensi yang dimiliki Kampung Tanjung Talok. Potensi tersebut tidak hanya terbatas pada sumber daya hasil laut, meskipun tidak dapat dipungkiri bahwa sumber daya laut merupakan potensi terbesar Kampung Tanjung Talok. Potensi yang dimiliki Kampung Tanjung Talok yaitu ikan, tumbuh-tumbuhan obat-obat-an, perkebunan. Nelayan di Kampung Tanjung Talok menjual hasil tangkapannya ke pasar-pasar tradisional. Hal serupa yang dilakukan oleh nelayan di Pasuruan dipasarkan pada pasar-pasar terdekat dan tidak keluar dari wilayah Pasuruan (Masud \& Wahid, 2020).

Perempuan Kampung Tanjung Talok mengolah ikan yang tidak dapat dijual sesuai dengan keahlian yang mereka miliki seperti kerupuk ikan, ikan asin dan sambal lumat. Pola yang sedang berkembang di Kampung Tanjung Talok sangat bagus jika dapat berkelanjutan, dimana tidak ada hasil ikan hasil melaut yang dibuang sia-sia. Selanjutnya, kondisi hasil laut yang dapat dikembangkan menjadi usaha sebatas kerupuk ikan, ikan asin dan sambal lumat. Hasil perkebunan yang dapat dikembangkan menjadi usaha yaitu ubi atau pisang menjadi keripik. Produk lainnya yaitu mengikuti keahlian perempuan Tanjung Talok dibidang kuliner seperti membuat rempeyek. Usaha-usaha tersebut dapat dijalankan oleh perempuan Tangjung Talok berdampingan dengan fungsi domestik sebagai ibu rumah tangga. Pengolahan hasil potensi Kampung Tanjung Talok sebatas membuat olahan ikan dan di pasarkan pada tetangga sekitar belum menggunakan model bisnis yang tepat. Potensi yang dimiliki sudah dimanfaatkan untuk dijadikan produk yang memiliki nilai ekonomi tetapi hal tersebut tidak didukung dengan pengemasan produk, pemasaran, analisis keuangan dan hal lainnya yang dapat mendukung keberlanjutan sebuah usaha rumahan.

\section{Peran perempuan Kampung Tanjung Talok dalam Pengembangan Usaha Kecil}

Berdasarkan hasil analisis yang telah dilakukan, diketahui bahwa pada umumnya perempuan Kampung Tanjung Talok sebagai ibu rumah tangga. Sehingga, kegiatan yang dilakukan oleh perempuan Kampung Tanjung Talok pada urusan domestik, mulai dari mempersiapkan kebutuhan suami sebelum dan sesudah pulang bekerja, dan mengurus segala kebutuhan rumah tangga. Sedangkan, disaat waktu luang perempuan Kampung Tanjung Talok belum memiliki kegiatan yang dapat meningkatkan perekonomian keluarga mereka. Keterbatasan aktivitas yang dilakukan oleh perempuan Kampung Tanjung Talok secara tidak langsung berdampak kepada perekonomian apalagi pada musim angin utara. Dimana musim angin utara adalah musim nelayan sulit untuk melaut dikarenakan cuaca yang ekstrim. Perempuan Kampung Tanjung Talok memiliki usaha kecil sebesar 13 persen, usaha kecil tersebut terdiri dari membuat kerupuk ikan, warung kelontong dan usaha makanan, kue kering, minyak gamat dan ikan asin.

Potensi sumber daya alam yang dimiliki Kampung Tanjung Talok sangat mempengaruhi peran perempuan di Tanjung Talok. Potensi utama yang dapat diolah menjadi produk di Kampung Tanjung Talok adalah ikan. Selain karena letak dari Kampung Tanjung Talok diwilayah pesisir, hal tersebut dipengaruhi dengan profesi sebagian besar kepala keluarga di Tanjung Talok adalah nelayan. Kegiatan yang dilakukan oleh perempuan Kampung Tanjung talok dalam menghasilkan produk makanan sangat sederhana. Mengolah dengan cara tradisional ikan yang didapat suami, dijadikan kerupuk, pengemasan dengan peralatan yang dimiliki dan pemasaran dilakukan di sekitar penduduk dan pasar tradisional. Menurut Ibu Helma mengatakan bahwa usaha yang ditekuni saat ini dalam membantu perekonomian keluarga adalah kerupuk ikan ringau. Di samping kegiatan seharihari sebagai ibu rumah tangga. Saat suami melaut, ibu menjalankan usaha warung sembako. Aktivitas yang dilakukan setelah suami melaut adalah menjual hasil melaut ke pasar tradisional. Selanjutnya membersihkan ikan untuk dijadikan kerupuk ikan. Jika musim ikan tinggi, usaha kerupuk ikan akan berdampak kepada perempuan pesisir lainnya. Seperti membantu untuk membersihkan ikan, mengolah ikan menjadi kerupuk. Sehingga usaha kerupuk yang ditekuni satu perempuan akan berdampak kepada perempuan lainnya di Kampung Tanjung Talok. Usaha yang dilakukan oleh bu Helma, juga dilakukan oleh bu Lana bahwa sudah selama 6 tahun menekuni usaha kerupuk ikan. Usaha yang dijalani sejalan dengan pekerjaan suami sebagai nelayan.

Membantu meningkatkan perekonomian rumah tangga, tidak semua ikan segar dari hasil melaut di jual ke tengkulak di pasar. Nilai ikan segar yang rendah dapat diolah menjadi ikan asin dan kerupuk ikan sehingga nilai jual semakin tinggi dibandingkan hanya menjual ikan segar hasil melaut yang tidak memiliki harga tinggi di pasaran. Peran yang dilakukan perempuan lebih banyak dilakukan pasca kepala keluarga melaut. Sejalan dengan penelitian yang dilakukan oleh (Peran Perempuan Pada Usaha Budidaya Rumput Laut.Pdf, n.d.) bahwa perempuan pesisir berperan lebih besar pada pasca melaut dibandingkan pada proses sebelum melaut. Perempuan sebelum suami melaut sebatas 
mempersiapkan bekal berupa makanan, kegiatan yang lebih beragam setelah suami melaut mempersiapkan makanan, menjual hasil melaut ke pasar, dan mengolah ikan yang tidak dijual untuk jadikan produk berupa kerupuk atau ikan asin.

Usaha perempuan Kampung Tanjung Talok tidak hanya sebatas usaha kerupuk ikan. Seperti Ibu Rohayati, beliau membuat minyak gamat yang dapat difungsikan untuk minyak pijat, luka kulit dan lainnya. Minyak gamat adalah minyak yang berbahan dasar dari teripang yang diolah dengan rempah-rempah. Selain menjual minyak gamat, lbu Rohayati membuka jasa pijat untuk membantu pereknonomian keluarga. Menurut lbu Rohayati, rendahnya hasil tangkapan melaut berdampak kepada perekonomian keluarga. Seperti, Ibu Rohayati menggunakan tabungan pribadi untuk membuat kelong karna hasil tangkapan ikan tidak dapat digunakan untuk modal dalam pembuatan kelong. Upaya peningkatan peran perempuan dalam peningkatan perekonomian lokal di Kampung Tanjung Talok dengan cara berpartisipasi dalam kelompok usaha bersama yang terdiri dari program pengembangan peran aktif perempuan sebagai penanggungjawab di kelompok usaha bersama dan program peningkatan peran aktif perempuan dalam mengikuti pelatihan pemasaran, pengemasan produk, label produk dan sertifikasi halal produk. Selanjutnya, (Sapitri, 2016) menyebutkan bahwa perempuan pesisir memiliki kemampuan untuk mengolah hasil sumber daya alam di kawasan menjadi produk yang dapat meningkatkan perekonomian masyarakat lokal.

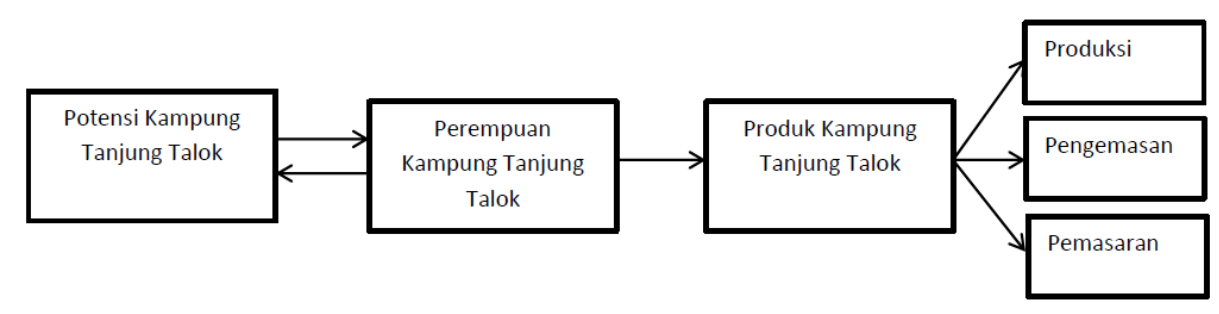

Gambar 3. Alur usaha rumah tangga di Kampung Tanjung Talok

Gambar di atas yang merupakan alur usaha rumah tangga di Kampung Tanjung Talok merupakan salah satu peran yang dilakukan oleh perempuan dalam membantu perekonomian keluarga. Alur yang telah dilaksanakan di Kampung Tanjung Talok belum maksimal, karna selama ini belum adanya pendampingan yang mengikat dengan usaha mereka. Pendampingan pada usaha kecil diperlukan, untuk melihat berjalanannya sebuah program dalam meningkatkan produktivitas di suatu usaha kecil. Seperti contoh, penelitian pada masyarakat desa Mundu Pasir Kabupaten Cirebon dilakukan pendampingan tidak hanya sebatas masyarakat sampai memiliki produk, tetapi dilakukan juga pendampingan mengenai manajemen usaha dan pemasaran produk agar masyarakat mendapatkan penghasilan dari produk yang dihasilkan (Adriyani et al., n.d.). Hal tersebutlah, yang belum dilakukan di lingkungan perempuan pesisir Kampung Tanjung Talok.

Sejauh ini, telah dibentuknya Kelompok Bersama (KUBE) Kampung Tanjung Talok. Dibentuknya KUBE dengan tujuan sebagai wadah bagi perempuan Kampung Tanjung Talok untuk menjalankan usaha rumahan dari hasil potensi kampung mereka dan memiliki manajemen yang terarah dengan berkolaborasi antara masyarakat di Kampung Tanjung Talok. Sayangnya, tidak semua perempuan di Kampung Tanjung Talok antusias dalam mengikuti KUBE, masyarakat yang telah memiliki usaha lebih memilih untuk mengembangkan usaha sendiri dibandingkan untuk ikut bagian dari KUBE. Selain bergabung dalam KUBE, perempuan Kampung Tanjung Talok telah memiliki usaha kecil seperti usaha pijat, menjual minyak gamat, membuat kerupuk ikan, membuat keripik, rempeyek, ikan asin, sambal lumat, warung makanan, warung minuman, kue, dan warung sembako. KUBE yang berada di Kampung Tanjung Talok belum dapat merangkul kebutuhan dari perempuan-perempuan, sehingga program yang dijalankan belum mencapai titik maksimal atau belum terangkulnya perempuan-perempuan yang menjadi target dalam pengembangan usaha rumahan.

Perempuan Kampung Tanjung Talok dibentuk kelompok usaha bersama yang dikenal dengan KUBE Tanjung Talok. KUBE Tanjung Talok beranggotakan perempuan Tanjung Talok dimana dibentuk KUBE untuk membuat produk usaha rumah tangga yang dapat mendatangkan manfaat ekonomi bagi perempuan Tanjung Talok. Produk yang dihasilkan dengan memanfaatkan potensi lokal yang dimiliki Kampung Tanjung Talok. KUBE Tanjung Talok dibentuk oleh Kepala Desa Teluk Sasah. Usaha yang dilakukan oleh perempuan di KUBE diharapkan dapat berjalan secara berkelanjutan, sehingga diperlukannya pendampingan dari berbagai stakeholder seperti perguruan tinggi, swasta dan pemerintah. Pendampingan tersebut dapat berupa mengenai pemasaran produk, sertifikasi produk, pengemasan dan label produk serta analisis keuangan usaha rumah tangga. 
Berdasarkan hal di atas, penulis membuat model perencanaan untuk program KUBE agar dapat merangkul perempuan-perempuan dan dapat langsung menjalankan program sesuai dengan kebutuhan dari kelompok KUBE masing-masing. Dalam meningkatkan usaha kecil dibentuk adanya model pengembangan, berdasarkan penelitian yang dilakukan oleh (Bismala, 2016) yaitu pengembangan dengan menggunakan model penggabungan manajemen sumber daya manusia, manajemen produksi, manajemen pemasaran, dan manajemen keuangan dengan dilakukannya analisis pada faktor internal dan eksternal dari usaha tersebut. Model tersebut dipandang praktis sehingga mudah untuk diterapkan oleh usaha kecil.

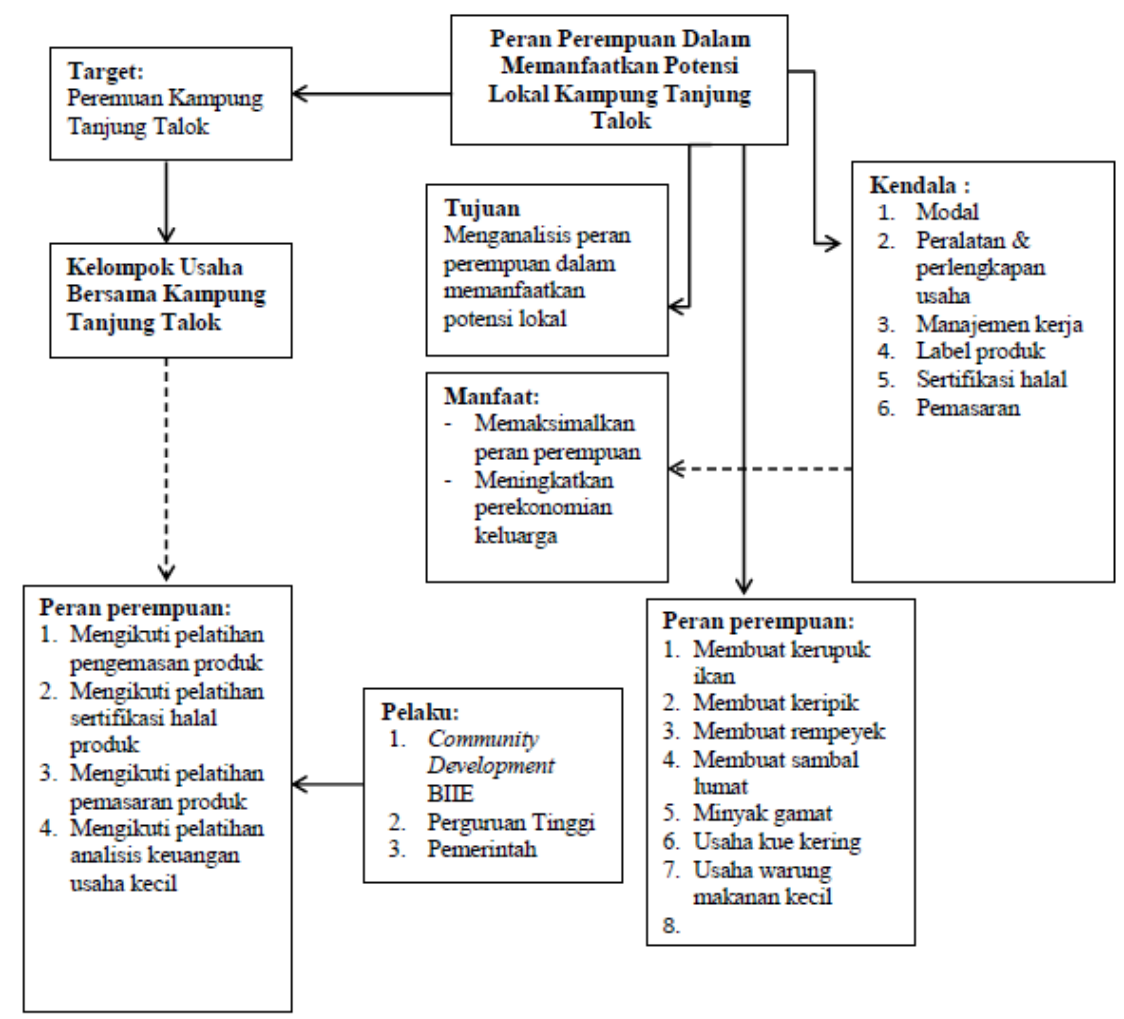

Gambar 4. Model perencaan memaksimalkan peran perempuan di Kampung Tanjung Talok

Berdasarkan model perencanaan di atas diketahui bahwa telah terbentuknya kelompok bersama (KUBE), yang telah dibentuk oleh Kepala Desa Teluk Sasah. Pada model ini, perempuan Tanjung Talok akan mengikuti pelatihan pengemasan produk, pelatihan sertifikasi halal produk, pelatihan pemasaran produk, pelatihan analisis keuangan usaha kecil. Pelatihan-pelatihan tersebut akan diadakan oleh community development PT BIIE, Perguruan Tinggi dan Pemerintah setempat. Selanjutnya, pelatihan-pelatihan tersebut terkait dengan kendala-kendala yang saat ini dihadapi oleh KUBE Tanjung Talok antara lain modal, peralatan \& perlengkapan usaha, manajemen kerja, label produk, sertifikasi halal dan pemasaran.

\section{Tantangan Perempuan Tanjung Talok Dalam Pengembangan Usaha Rumah Tangga}

Tidak sedikit tantangan yang didapat oleh perempuan pesisir dalam pengembangan usaha rumah tangga. Menurut (Istikomayanti et al., 2018), tantangan yang dihadapi ibu rumah tangga dalam pengembangan usaha kecil adalah meningkatkan kepercayaan diri dalam berwirausaha ibu rmah tangga, pemasaran yang lebih luas, menjaga kualitas produk agar dapat berdaya saing. Hal tersebut dialami oleh perempuan Tanjung Talok dalam pengembangan usaha rumah tangga seperti:

1. Modal

Selama manjalankan usaha kerupuk ikan, perempuan pesisir dimana suami adalah seorang nelayan hanya mengandalkan hasil tangkapan suami berupa ikan yang memiliki harga jual rendah di pasar. Mereka tidak mematokan keuangan untuk usaha kerupuk ikan, hal tersebut hanya bergantung dari hasil tangkapan suami sebagai nelayan.

2. Peralatan dan perlengkapan usaha

Peralatan yang digunakan dalam membuat usaha dari sumber daya alam atau potensi yang dimiliki Kampung Tanjung Talok masih terbatas. Dengan keterbatasan peralatan yang mereka 
miliki, salah satu produk seperti kerupuk ikan hanya di jual dalam bentuk tidak siap di konsumsi langsung. Dari hasil wawancara yang dilakukan oleh penulis bahwa peralatan yang dapat menunjang seperti mesin pres plastik, pemotong adonan kerupuk ikan dan blender penggiling daging agar nilai kerupuk yang dihasilkan semakin berkualitas. Pada tahun 2003 bantuan berupa peralaytan pembuatan tikar mending dan sale pisang diberikan oleh Segara Anakan Conservation and Development Project (SACDP) spesialis Pemberdayaan Perempuan KPKSA (Pembentukan Model Pemberdayaan Perempuan Nelayan Di Daerah Tertinggal, n.d.).

3. Manajemen Kerja

Kampung Tanjung Talok telah memiliki kelompok usaha bersama. Kelompok ini dibentuk sebagai wadah bagi perempuan Tanjung Talok untuk lebih mengembangkan potensi yang ada di Kampung Tanjung Talok dalam bentuk nilai ekonomi. Menurut masyarakat setempat, mengalami kesulitan dalam membagi cara kerja dengan jumlah anggota yang terlalu banyak. Selanjutnya, waktu kesibukan yang berbeda akan menjadi kendala dalam mengumpulkan anggota kelompok. Tetapi kelompok lain berpendapat bahwa hal tersebut bukanlah merupakan suatu permasalahan, mereka dapat membagi kerja dengan kemampuan dan keahlian yang dimiliki masing-masing anggota, misalkan ada yang membersihkan ikan, menggiling ikan, membentuk, dan menjual. Kegiatan-kegiatan tersebut dapat dilakukan di rumah masing-masing warga tanpa harus berkumpul dan mengorbankan waktu yang mereka miliki untuk mengerjakan kegiatan domestik.

4. Label produk

Keterbatasan yang dimiliki warga adalah dalam memberikan label di produk yang mereka hasilkan. Keterbatasan tersebut tidak terlepas dari pengalaman dan ilmu yang mereka dapatkan. Dalam hal ini, perlunya pendampingan khusus dalam label produk, sehingga produk tersebut mendapatkan tempat di pasar dan dapat memperluas pasar yang saat ini. Saat ini produk diperjual belikan pada masyarakat setempat dan pasar tradisional.

5. Label halal produk

Kendala yang dirasakan warga dalam menjual produk yang dimiliki adalah belum adanya label halal atau sertifikasi halal pada produk yang mereka hasilkan. Mereka tidak berani untuk memasarkan produk pada pasar yang lebih luas karna belum terdapat sertifikasi halal pada produk. Hal tersebut akan berdampak kepada produk tidak akan diterima di pasar dan menurunnya kepercayaan konsumen pada produk yang belum memiliki label halal. Dalam hal ini, sangat penting untuk mendampingi warga dalam sertifikasi halal produk. Prosedur dan persyaratan yang dapat dipenuhi oleh warga.

6. Pemasaran produk

Hal terakhir jika hal di atas telah terpenuhi, dalam pemasaran, baik untuk ke toko cendramata, mini market, dan daerah-daerah wisata. Produk Kampung Tanjung Talok memiliki peluang menjadi oleh-oleh khas kuliner Kampung Tanjung Talok.

\section{KESIMPULAN DAN SARAN}

Potensi-potensi yang dimiliki Kampung Tanjung Talok beragam, baik dari segi pertanian , buah-buahan dan kelautan. Potensi terbesar adalah kelautan, hal tersebut berdasarkan letak geografis dari Kampung Tanjung Talok yang berada pada kawasan pesisir. Sehingga Sebagian besar masyarakat berprofesi sebagai nelayan. Pendapatan nelayan dapat dikatakan tidak tetap, karna tergantung musim yang mempengaruhi banyaknya hasil melaut. Oleh sebab itulah, perempuan Kampung Tanjung Talok dituntut untuk dapat mengolah hasil laut sehingga tidak hanya di jual mentah ke pasar tetapi dapat menjadi produk yang memiliki nilai ekonomi. Sedangkan potensi lainnya, seperti hasil buah-buahan (pisang) dapat diolah menjadi keripik pisang. Dalam memanfaatkan hasil laut yang dimiliki, perempuan Tanjung Talok mengolah hasil laut menjadi produk seperti kerupuk ikan, ikan hasil, dan sambal lumat. Kelamahannya adalah belum terbentuknya model perencanaan yang bersinergi satu sama lain. Sejauh ini, perempuan Kampung Tanjung Talok sebatas menggunakan kemampuan dan pengetahuan yang mereka miliki dalam menjual produk. Belum terdapatnya pemasaran, pengemasan, analisis keuangan dalam produk yang mereka pasarkan. Sehingga, penting adanya model perencanaan untuk dapat menjadi gambaran kerja usaha perempuan Kampung Tanjung Talok. Usaha yang ada dan yang akan dijalankan oleh perempuan Kampung Tanjung Talok tidak terlepas dari tantangan. Dalam hal modal usaha dan peralatan usaha, perempuan Tanjung Talok mendapat dukungan dana dari pihak swasta yang menjadi dasar bagi mereka dalam pengembangan produk. Selanjutnya tantangan lainnya seperti pemasaran, pengemasan, menajemen kerja, sertifikasi produk akan dilewati oleh masyarakat Kampung Tanjung Talok berdasarkan model perencanaan yang ada dengan bekerja sama dengan perguruan tinggi, 
pemerintah dan pihak swasta. Sehingga, peran dari perempuan Kampung Tanjung Talok dalam memproduksi produk dapat maksimal sampai pada tahap pemasaran. Saran untuk penelitian selanjutnya adalah menganalisis model perencanaan yang telah dibuat untuk diaplikasikan sesuai dengan kebutuhan. Selanjutnya, sejauh apa model tersebut efektif untuk berkembangnya usaha kecil masyarakat Kampung Tanjung Talok

\section{REFERENCES}

Adriyani, R., Widianti, N., \& Siswanto, A. (N.D.). Pemanfaatan Sisa Olahan Ikan Dan Rajungan Sebagai Income Generic Bagi Masyarakat Mundu Pesisir Kabupaten Cirebon. 17.

Amsal Dan Junawati.Pdf. (N.D.).

Andani, F. (2017). Peran Perempuan Dalam Kegiatan Pariwisata Di Kampung Wisata Tebing Tinggi Okura Kota Pekanbaru. 4(2), 11.

Anggraini, Y. (2018). Peran Perempuan Masyarakat Pesisir Dalam Meningkatkan Pendapatan Keluarga Nelayan Di Desa Bayah Kecamatan Bayah Kabupaten Lebak. 13, 10.

Astanty, W. F. (N.D.). (Studi Kasus Di Desa Punaga Kec.Mangarabombang). 10.

Bismala, L. (2016). Model Manajemen Usaha Mikro Kecil Dan Menengah (Umkm) Untuk Meningkatkan Efektivitas Usaha Kecil Menengah. 5, 8.

Donna Np Butarbutar, Lelo Sintani, \& Luluk Tri Harinie. (2020). Peningkatan Kesejahteraan Ekonomi Masyarakat Pesisir Melalui Pemberdayaan Perempuan. Journal Of Environment And Management, 1(1), 31-39. Https://Doi.Org/10.37304/Jem.V1i1.1203

Handajani, H., Relawati, R., \& Handayanto, E. (2016). Peran Gender Dalam Keluarga Nelayan Tradisional Dan Implikasinya Pada Model Pemberdayaan Perempuan Di Kawasan Pesisir Malang Selatan. Jurnal Perempuan Dan Anak, 1(1). Https://Doi.Org/10.22219/Jpa.V1i1.2745

Hariyanto, T., Baskoro, M. S., Haluan, J., \& Iskandar, B. H. (2008). Pengembangan Teknologi Penangkapan Ikan Berbasis Komoditas Potensial Di Teluk Lampung. 3(2), 7.

Hendriyana, H., Putra, I. N. D., \& Sunarya, Y. Y. (2020). Industri Kreatif Unggulan Produk Kriya Pandan Mendukung Kawasan Ekowisata Pangandaran, Jawa Barat. Panggung, 30(2). Https://Doi.Org/10.26742/Panggung.V30i2.1202

Hidayat, A., \& Safitri, P. (2019). Pengembangan Komoditas Rumput Laut Nusa Tenggara Barat Dengan Model Hexagon Untuk Pembangunan Ekonomi Lokal. Jurnal Kebijakan Sosial Ekonomi Kelautan Dan Perikanan, 9(1), 45. Https://Doi.Org/10.15578/Jksekp.V9i1.7359

Hidayatullah, F. A., \& Suminar, T. (2021). Strategi Pemberdayaan Masyarakat Berbasis Potensi Lokal Candi Plaosan Melalui Program Desa Wisata Untuk Kemandirian Ekonomi Di Desa Bugisan Kecamatan Prambanan Kabupaten Klaten. 1(1), 11.

Istikomayanti, Y., Bariska, H. F., \& Dwi Susanti, R. A. (2018). Tantangan Pemberdayaan Perekonomian Kecil Melalui Usaha Kelompok Ibu Rumah Tangga (Irt). Jast : Jurnal Aplikasi Sains Dan Teknologi, 2(1), 6. Https://Doi.Org/10.33366/Jast.V2i1.946

Kamil, I., \& Hapsari, I. (N.D.). Pengembangan Model Industri Kelautan Berbasis Klaster Di Kota Padang. Jurnal Optimasi Sistem Industri, 6(2), 6.

Masud, M. I., \& Wahid, A. (2020). Model Pengembangan Pengelolaan Hasil Tangkap Ikan Masyarakat Pesisir Kabupaten Pasuruan Melalui Pendekatan Linear Programming Dan Business Model Canvas Dalam Industri 4.0. Agromix, 11(1), 115-124. Https://Doi.Org/10.35891/Agx.V11i1.1672

Nawawi, M., Purnomo, D., Bunyamin, A., Sembiring, A., \& Hindasah, L. (2020). Community Potential Mapping For Activating And Developing Social Entrepreneur Based On Local Commodity In Berau Regency, East Kalimantan. IOP Conference Series: Earth And Environmental Science, 443, 012073. Https://Doi.Org/10.1088/1755-1315/443/1/012073

Nurlaili, N., \& Muhartono, R. (2017). Peran Perempuan Nelayan Dalam Usaha Perikanan Tangkap Dan Peningkatan Ekonomi Rumah Tangga Pesisir Teluk Jakarta. Jurnal Sosial Ekonomi Kelautan Dan Perikanan, 12(2), 203. Https://Doi.Org/10.15578/Jsekp.V12i2.6481

Nwabeze, G. O., Ifejika, P. I., Tafida, A. A., Ayanda, J. O., Erie, A. P., \& Belonwu, N. E. (2012). Gender And Fisheries Of Lake Kainji, Nigeria: A Review. Journal Of Fisheries And Aquatic Science, 8(1), 9-13. Https://Doi.Org/10.3923/Jfas.2013.9.13

Pembentukan Model Pemberdayaan Perempuan Nelayan Di Daerah Tertinggal. (N.D.). 1.

Peran Perempuan Pada Usaha Budidaya Rumput Laut.Pdf. (N.D.).

Rad, S. T. (N.D.). An Application Of A Women-Oriented Agro-Tourism Rural Development Model In Improving Local Economy. 10.

Sapitri, N. (2016). Analisis Faktor Risiko Kejadian Hipertensi Pada Masyarakat Di Pesisir Sungai Siak Kecamatan Rumbai Kota Pekanbaru. 3(1), 15. 
Tahawila, A. (N.D.). Studi Akar Kemiskinan Nelayan Di Kelurahan Baiya Kecamatan Tawaeli Kota Palu. 10.

The Role Of Women In Fisheries.Pdf. (N.D.). 